\title{
INVITRO ANTIBACTERIAL ACTIVITY OF TAMRA BHASMA
}

\author{
Prasanna Kumar $T^{1^{*}}$, Vijay Kumar GS $^{2}$, Shwetha Singh $^{3}$
}

\begin{abstract}
Tamra bhasma [copper ash] is used in treating various disorders like jvara [fever], twakvikaras [skindisorders] etc based on its antipyretic, anti parasitic and antileprotic properties mentioned in our classics. The present study was undertaken to evaluate antibacterial role of tamra bhasma on gram positive and gram negative bacteria. Material and methods: Tamra and other raw drugs such as Parada [mercury] and Gandhaka [sulphur] were purified and shudha tamra was subjected to marana [incineration] process according to the procedures mentioned in classics. MIC and MBD of the prepared sample was determined by broth dilution method by following NCCLS guidelines. Results: Tamra bhasma had an antibacterial effect against both gram positive and gram negative bacteria. Minimum Inhibition Concentration [MIC] and Minimum Bactericidal Dose [MBD] was estimated to be $2.5 \mathrm{mg} / \mathrm{ml}$ of nutrient Broth for E. coli and between $1.25 \mathrm{mg} / \mathrm{ml}$ for Staphylococcus. Conclusion: The exact therapeutic dose detection needs further detailed analysis.
\end{abstract}

Key Words: Minimum inhibitory concentration (MIC), Minimum bactericidal dose (MBD), Tamra Bhasma, Jvaraghna, Krimighna, Kushtaghna.

\section{Introduction:}

Tamra has been used in preparing various medicines for thousands of years. Our ancient classics mentions the therapeutic use of copper in treating various disorders such as abhisyanda [conjunctivitis], krimiroga [antihelminthic \& antiparasitic], visuchika [cholera], various jvaras [fever], tvakvikaras [skin disorders] etc.

The following Historical review on copper shows it has antibacterial effect

The first medical use of copper found in Papyrus, The Egyptian Medical Text, records use of copper in sterilizing chest wounds.

Acharya susruta mentioned preparation of Shalaka [needle] out of Tamra in operation of cataract.

In Hippocratic collection copper was recommended in the treatment of leg ulcers associated with varicose veins.

Greeks used dry powder composed of copper oxide and copper sulphate on the wound.
Inorganic copper preparations were found to be effective in treating eczema, impetigo, tubercular infections etc.

Thus based on its use on certain bacterial infections since ancient times and important properties such as jvaraghna, krimighna and kushtaghna mentioned in our classics present study on tamra bhasma was undertaken to prove its efficacy as an antibacterial agent.

\section{AIMS AND OBJECTIVES:}

To carry out Purification of the raw drugs - Parada [Mercury], Gandhaka [Sulphur] and Tamra [Copper]. Ash]

To prepare Tamra Bhasma [Copper

To find the Antibacterial action of the prepared sample and

To determine the MIC \& MBD of prepared sample against gram positive bacteria and gram negative bacteria.

MATERIALS AND METHODS:

Raw materials were collected from genuine sources and subjected initially for the purification process.

1* Corresponding Author: Assistant Professor, Department of P.G. Studies in Rasashastra, JSS Ayurveda Medical College, Mysore, Karnataka, India, Tel: +919916482581, E.mail: drprasannakumart@gmail.com, 2. Professor and HOD, Department of Microbiology, JSS Medical College, Mysore,

3. P.G. Scholar, Department of P.G. Studies in Rasashastra, JSS Ayurveda Medical College, Mysore. 


\section{PARADA SHODHANA [MERCURY PURIFICATION] (1)}

Reference : Rasendra sara samgraha $1 / 28$

Method : Urdhva patana method

Equipments : Khalva yantra, Urdhva patana yantra,

Ingredients : Ashudha parada $-500 \mathrm{~g}$,

Kumari svarasa [aloe vera juice]- Q.S, Haridra [turmeric] $-500 \mathrm{~g}$

Procedure: Mercury and Turmeric taken in known quantity was triturated well till the complete mercury is assimilated into Turmeric then aloe vera juice was added and chakrikas [small thin plates] were prepared with it. Chakrikas are dried and placed into urdhva patana yantra [equipment to procure mercury] and subjected for heating for 6 hours. After self cooling mercury was collected and washed thoroughly in hot water for 3-5 times.

Observations:

\begin{tabular}{|l|l|l|}
\hline Parada & $\begin{array}{l}\text { Before } \\
\text { shodhana }\end{array}$ & $\begin{array}{l}\text { After } \\
\text { shodhana [a] }\end{array}$ \\
\hline Weight & $500 \mathrm{~g}$ & $478 \mathrm{~g}$ \\
\hline Appearance & Dull shine, & $\begin{array}{l}\text { Lustrous, clear } \\
\text { and shiny }\end{array}$ \\
\hline
\end{tabular}

\section{GANDHAKA \\ SHODHANA \\ [PURIFICATION OF SULPHUR] (15)}

Reference: Rasa ratna samuchaya 3/21-23

Method: Bhudhara method

Equipments: Mud pot, Sthali yantra

Ingredients: Gandhaka - 500g, Godugdha

- 2litres
Procedure: $\quad$ Mud pot was filled with godugdha and gandhaka was placed on cloth tied over its mouth and covered with sthali yantra. vanyopalas [cow dung cakes] placed above in sufficient quantity and ignited after self cooling gandhaka collected in the milk was collected and washed in hot water.

Observations:

\begin{tabular}{|l|l|l|}
\hline Gandhaka & $\begin{array}{l}\text { Before } \\
\text { shodhana }\end{array}$ & $\begin{array}{l}\text { After } \\
\text { shodhana }[b]\end{array}$ \\
\hline Weight & $500 \mathrm{~g}$ & $496 \mathrm{~g}$ \\
\hline Appearance & $\begin{array}{l}\text { Yellow, } \\
\text { Crystalline }\end{array}$ & $\begin{array}{l}\text { Small } \\
\text { Globular and } \\
\text { lustrous }\end{array}$ \\
\hline
\end{tabular}

\section{TAMRA GENERAL AND SPECIFIC PURIFICATION: (1-12)}

References: Rasa ratna samuchaya 5/29

Equipments: Steel vessel

Ingredients:

samanya shodhana [general purification] Tamra $-1 \mathrm{~kg}$, Tilataila, takra, gomutra, aranala, kulatha kwatha, in sufficient quantity

Vishishta shodhana [specific purification] - samanya shodhita tamra, nirgundi swarasa and saindhava lavana, nimbu rasa [lemon juice] in quantity sufficient Procedure: samanya shodhana was done by heating and dipping for 7 times in each above said liquid.and Vishishta shodhana was done by applying paste of saindhava and nimbu rasa on tamra patra heating and dipping it in nirgundi rasa this process was done for 8 times

Observations: copper general purification and specific purification

\begin{tabular}{|l|l|l|l|l|}
\hline TAMRA & $\begin{array}{l}\text { Initial } \\
\text { weight }\end{array}$ & $\begin{array}{l}\text { Final } \\
\text { weight }\end{array}$ & $\begin{array}{l}\text { Weight } \\
\text { loss }\end{array}$ & Observed changes \\
\hline Taila [Oil] & $995 \mathrm{~g}$ & $995 \mathrm{~g}$ & No loss & $\begin{array}{l}\text { Tamra became soft and } \\
\text { blackish discoloration }\end{array}$ \\
\hline Takra [Buttermilk] & $993 \mathrm{~g}$ & $1.025 \mathrm{~kg}$ & Gain-32g & $\begin{array}{l}\text { Tamra had dark grey layers } \\
\text { that peels easily }\end{array}$ \\
\hline Gomutra [Cow's urine] & $1.025 \mathrm{~kg}$ & $1.015 \mathrm{~kg}$ & $\begin{array}{l}\text { Loss- } \\
10 \mathrm{~g}\end{array}$ & Grayish black, fragile, \\
\hline Aranala & $1.015 \mathrm{~kg}$ & $950 \mathrm{~g}$ & Loss-65g & Grayish layers peels easily, \\
\hline Kulatha [Decoction] & $950 \mathrm{~g}$ & $925 \mathrm{~g}$ & Loss-25g & Tamra became still more \\
\hline
\end{tabular}




\begin{tabular}{|l|l|l|l|l|}
\hline & & & & brittle \\
\hline $\begin{array}{l}\text { Nirgundi Rasa [Juice of } \\
\text { Vitex Nirgundo] }\end{array}$ & $500 \mathrm{~g}$ & $575 \mathrm{~g}$ & Gain-75g & $\begin{array}{l}\text { Tamra powdered easily } \\
\text { saltish taste and smell }\end{array}$ \\
\hline
\end{tabular}

\section{KAJJALI PREPARATION: [E]}

INGREDIENTS: shudha [purified] Parada - 500g, shudha gandhaka $500 \mathrm{~g}$.

Procedure: mardana of parada and gandhaka was done till the jet black powder was obtained

Observation: triturating done for 62 hours, prepared kajjali was jet black lusterless and soft. Weight - before trituration was $1000 \mathrm{~g}$ and after trituration $-970 \mathrm{~g}$. So total loss is $30 \mathrm{~g}$

\section{TAMRA BHASMA (3) [F]}

Reference : Rasa tarangini 5/51

Method : Incineration [marana]

Equipments: Khalva yantra [mortar pestle] , sharava,vanyopalas [cowdung cakes] Ingredients: Kajjali - 2pts[300g], shudha tamra $[150 \mathrm{~g}]$ - 1pt ,lemon juice-qs

Procedure: kajjali and lemon juice paste was applied on copper and subjected to incineration process by heating with 1000 cow dung cakes each time and after $10^{\text {th }}$ puta genuine copper ash was obtained which passed all the classical bhasma pareekshas [tests for genunity].

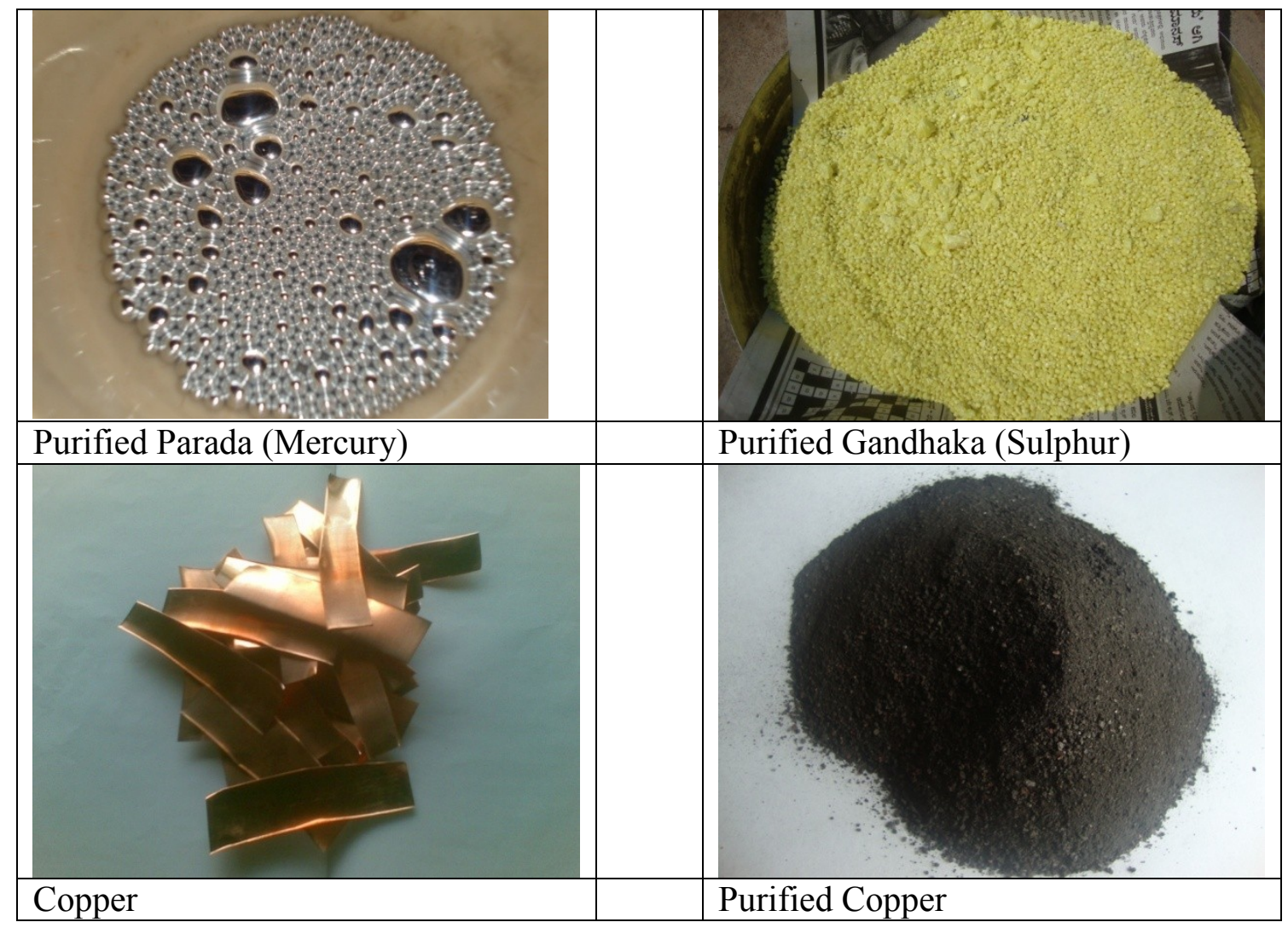




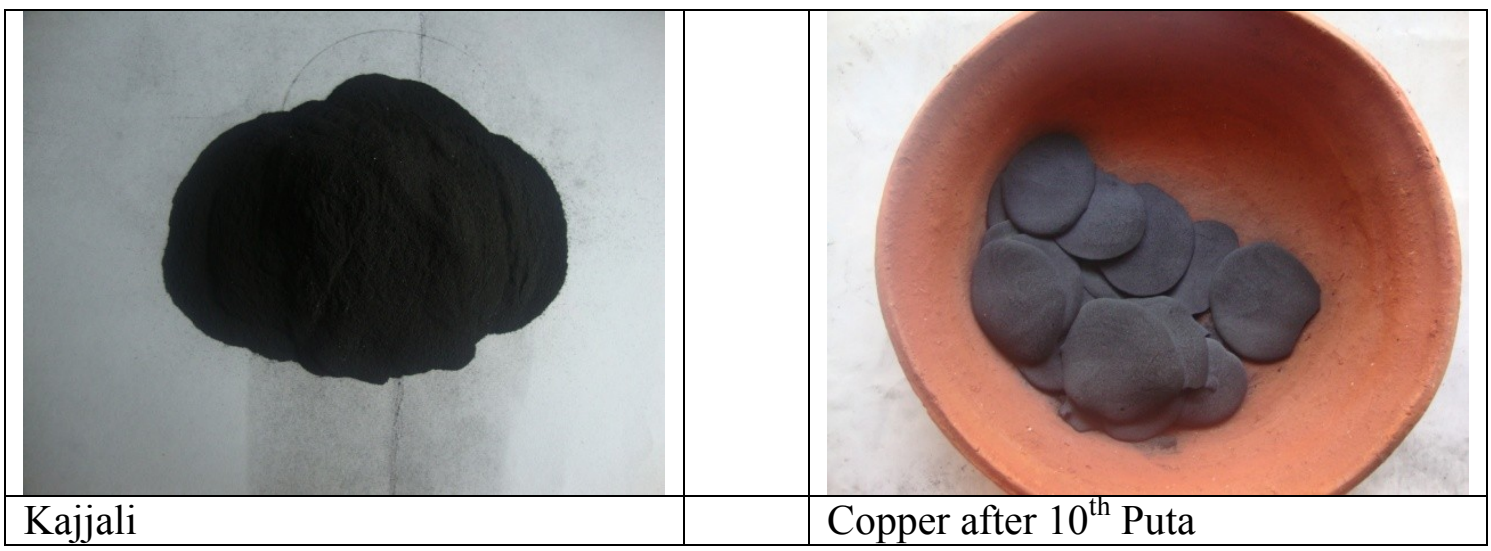

Observations:

\begin{tabular}{|c|c|c|c|c|c|c|c|c|c|c|}
\hline Puta & First & $\begin{array}{l}\text { Seco } \\
\text { nd }\end{array}$ & Third & fourth & Fifth & Sixth & seventh & eight & ninth & $\begin{array}{l}\text { Tent } \\
\mathrm{h}\end{array}$ \\
\hline $\begin{array}{l}\text { Kajjali } \\
\text { taken }\end{array}$ & $300 \mathrm{~g}$ & $250 \mathrm{~g}$ & $240 \mathrm{~g}$ & $240 \mathrm{~g}$ & $230 \mathrm{~g}$ & $226 \mathrm{~g}$ & $210 \mathrm{~g}$ & $196 \mathrm{~g}$ & $170 \mathrm{gg}$ & $220 \mathrm{~g}$ \\
\hline $\begin{array}{l}\text { Tamra } \\
\text { taken }\end{array}$ & $150 \mathrm{~g}$ & $125 \mathrm{~g}$ & $120 \mathrm{~g}$ & $119 \mathrm{~g}$ & $115 \mathrm{~g}$ & 113 & $105 \mathrm{~g}$ & $98 \mathrm{~g}$ & $85 \mathrm{~g}$ & $110 \mathrm{~g}$ \\
\hline $\begin{array}{l}\text { Weight } \\
\text { before } \\
\text { puta }\end{array}$ & $450 \mathrm{~g}$ & $375 \mathrm{~g}$ & $360 \mathrm{~g}$ & $360 \mathrm{~g}$ & $350 \mathrm{~g}$ & $115 \mathrm{~g}$ & $107 \mathrm{~g}$ & $102 \mathrm{~g}$ & $175 \mathrm{~g}$ & $220 \mathrm{~g}$ \\
\hline $\begin{array}{l}\text { Weight } \\
\text { after } \\
\text { puta }\end{array}$ & $145 \mathrm{~g}$ & $120 \mathrm{~g}$ & $119 \mathrm{~g}$ & $115 \mathrm{~g}$ & $113 \mathrm{~g}$ & $105 \mathrm{~g}$ & $98 \mathrm{~g}$ & $97 \mathrm{~g}$ & $107 \mathrm{~g}$ & $108 \mathrm{~g}$ \\
\hline $\begin{array}{l}\text { Vanyop } \\
\text { alas }\end{array}$ & 1000 & 1000 & 1000 & 1000 & 1000 & 1000 & 1000 & 1000 & 1000 & 1000 \\
\hline $\begin{array}{l}\text { Observ } \\
\text { ation }\end{array}$ & $\begin{array}{l}\text { blac } \\
\text { kish } \\
\text { gree } \\
\mathrm{n}\end{array}$ & $\begin{array}{l}\text { Blac } \\
\text { kish } \\
\text { with } \\
\text { green } \\
\text { and } \\
\text { brow } \\
\mathrm{n} \\
\text { tinge } \\
\end{array}$ & $\begin{array}{l}\text { Brow } \\
\text { nish } \\
\text { black } \\
\text { and } \\
\text { soft } \\
\text { than } \\
\text { befor } \\
\text { e }\end{array}$ & $\begin{array}{l}\text { Shine } \\
\text { reduced } \\
\text { comparati } \\
\text { vely } \\
\text { Chakrikas } \\
\text { soft and } \\
\text { easily } \\
\text { breakable }\end{array}$ & $\begin{array}{l}\text { Black } \\
\text { and } \\
\text { easily } \\
\text { powdere } \\
\text { d }\end{array}$ & $\begin{array}{l}\text { Blackis } \\
\mathrm{h} \\
\text { brown }\end{array}$ & $\begin{array}{l}\text { Browni } \\
\text { sh on } \\
\text { powder } \\
\text { ing }\end{array}$ & $\begin{array}{l}\text { Black } \\
\text { color } \\
\text { ed } \\
\text { chakr } \\
\text { ikas }\end{array}$ & $\begin{array}{l}\text { Brown } \\
\text { tinge }\end{array}$ & $\begin{array}{l}\text { Blac } \\
\text { kish } \\
\text { brow } \\
\text { n }\end{array}$ \\
\hline $\begin{array}{l}\text { Bhasm } \\
\text { a } \\
\text { pareeks } \\
\text { ha } \\
\text { Test for } \\
\text { genuini } \\
\text { ty of } \\
\text { bhasma }\end{array}$ & - & - & - & $\begin{array}{l}\text { Varitaratv } \\
\text { a-ve } \\
\text { Rekhapoo } \\
\text { rnatva } \\
+ \text { ve }\end{array}$ & $\begin{array}{l}\text { Varitara } \\
\text { tva-ve }\end{array}$ & $\begin{array}{l}\text { Varitar } \\
\text { atva- } \\
80 \% \\
\text { passed }\end{array}$ & $\begin{array}{l}\text { Varitar } \\
\text { atva- } \\
95 \% \\
\text { passed } \\
\text { Curd } \\
\text { test } \\
\text { passed }\end{array}$ & $\begin{array}{l}\text { Unam } \\
\text { a } \\
\text { positi } \\
\text { ve } \\
\text { Curd } \\
\text { test } \\
\text { +ve }\end{array}$ & $\begin{array}{l}\text { Apunarb } \\
\text { hasva } \\
\text { passed } \\
\text { Niruth } \\
\text { passed }\end{array}$ & $\begin{array}{l}\text { All } \\
\text { the } \\
\text { tests } \\
\text { passe } \\
d\end{array}$ \\
\hline
\end{tabular}

\section{ANTIBACTERIAL STUDY}

After the sample was prepared the antibacterial study was conducted in Department of Microbiology, JSS Medical College Mysore.
Methodology:

Preparatory procedures:

A] Four different methods were adapted to make tamra bhasma suitable for this study. 
1. Sample I - Preparation of stock solution by adding $1 \mathrm{~g}$ of tamra bhasma sample in $10 \mathrm{ml}$ of distilled water

2. Sample II - Preparation of tamra bhasma paste by triturating well.

3. Sample III - Pure filtrate was obtained from the original stock solution

4. Sample IV - Solution obtained by diluting pure Filtrate with equal amount of distilled water

B] Control groups:

Positive control group: In which bacterial suspension was maintained to check the

Viability of organisms

Negative control group: Was only distilled water for validation of the test was used.

C] Gentamycin in different solution with particular dose was used for comparison at the same time.

D] A suspension was prepared with standard strains of E. coli and Staphylococcus.

\section{METHOD ADOPTED: Invitro Study by Broth Dilution Method (16)}

The Antibacterial action of the prepared tamra bhasma was tested against both gram positive cocci and gram negative bacilli. MIC \& MBD of the sample was determined by following NCCLS guidelines.

In the present study ATCC strains of gram positive bacteria (Staphylococcus Aureus) and gram negative Bacilli (E coli) was selected as these are the common agents of infections including Nosocomial infections.

- Sample I [G] -Tamra bhasma was made into fine powder and stock solution was prepared by adding $10 \mathrm{ml}$ of distilled water to $1 \mathrm{~g}$ of sample.

From this stock solution different dilutions of bhasma in decreasing concentration was prepared ranging from $0.1 \mathrm{~g}$ to $0.0125 \mathrm{~g} / \mathrm{ml}$ of nutrient broth in this way two sets of test tubes was prepared and named as set $\mathrm{A}$ and set $\mathrm{B}$

To each of these set of test tubes 1 loop full of each bacterial suspension [staph and E. coli] matching to 0.5 mcfarland turbidity standard was added. Set A test tubes were inoculated with $E$. coli and set B was inoculated with Staphylococcus. All the test tubes were then incubated at $37 \mathrm{c}$ for 18-24 hrs.

Sample II [F]- Tamrabhasma paste was prepared by triturating well with known quantity of distilled water and dilutions were prepared with decreased concentrations of sample. Two such sets of test tubes were sample concentration ranging from $5 \mathrm{mg}$ to $0.15 \mathrm{mg} / \mathrm{ml}$ of nutrient broth were made and named as set $a$ and set $b$. these sets were also inoculated with bacterial suspensions in the same manner and incubated at $37 \mathrm{c}$ for 18-24 hours.

Similarly the III sample - pure filtrate and the IV sample - dilute solution of filtrate were prepared and $1 \mathrm{ml}$ of each sample was taken with one $\mathrm{ml}$ of nutrient broth in different test tubes and each of these were inoculated with bacterial suspensions and incubated for $18 \mathrm{hrs}$.

Negative and positive control groups and gentamycin dilutions were also prepared at the same time.

After $18 \mathrm{hrs}$ of incubation test tubes were taken out and wet mount preparation was done for each of the dilutions and examined microscopically for viability of the bacteria. At the same time from each test tubes and also from the control group one loop full of material were aseptically inoculated on a blood agar plate. And all the blood agar plates were incubated at $37 \mathrm{c}$ for 18 hours.

On the third day blood agar plates were examined for presence or absence of bacterial growth [colony formation] which shows no action or effective action of the samples respectively. 
OBSERVATIONS: After 18 hours of incubation of blood agar plates.

\begin{tabular}{|l|l|l|}
\hline Blood agar plates & E. coli (Gram -ve bacilli) & $\begin{array}{l}\text { STAPHYLOCOCCUS (Gram +ve } \\
\text { cocci) }\end{array}$ \\
\hline Positive control group & Growth present & Growth present \\
\hline Negative control group & Growth absent & Growth absent \\
\hline $\begin{array}{l}\text { Gentamycin dilution test } \\
\text { tubes }\end{array}$ & Growth absent & Growth absent \\
\hline Sample I [0.1g-0.0125g] & Growth absent [I] & Growth absent [I] \\
\hline Sample II [5mg-0.15mg] & $\begin{array}{l}\text { Growth absent in 5mg } \\
\text { 2.5mg [J] }\end{array}$ & $\begin{array}{l}\text { Growth } \\
5 \mathrm{mg}, 2.5 \mathrm{mg}, 1.25 \mathrm{mg}[\mathrm{K}]\end{array}$ \\
\hline $\begin{array}{l}\text { Sample III [pure filtrate of } \\
\text { sample] }\end{array}$ & Growth absent [L] & Growth absent [L] \\
\hline $\begin{array}{l}\text { Sample IV [ dilute filtrate } \\
\text { solution] }\end{array}$ & Growth absent & Growth absent \\
\hline
\end{tabular}

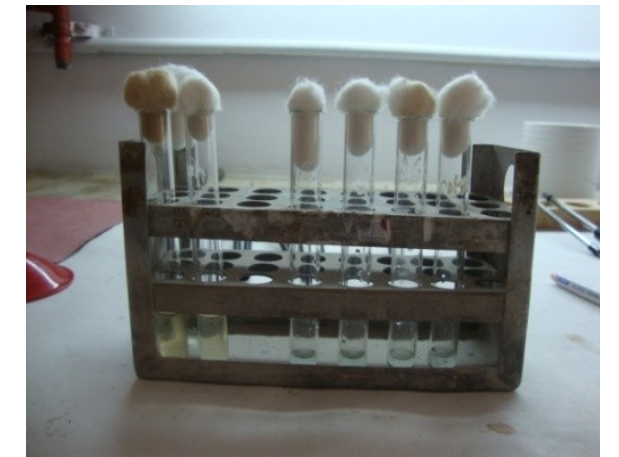

G] BROTH DILUTION SAMPLE I

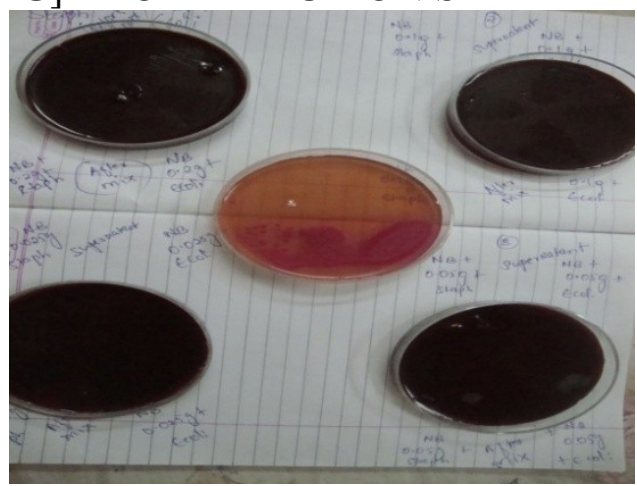

[I]

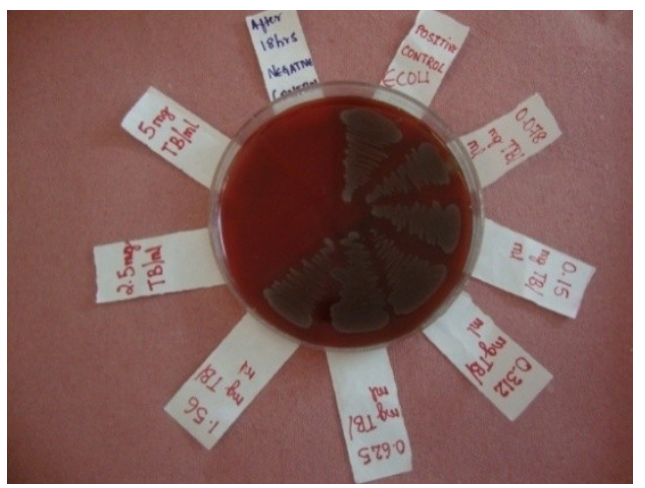

$[\mathbf{K}]$

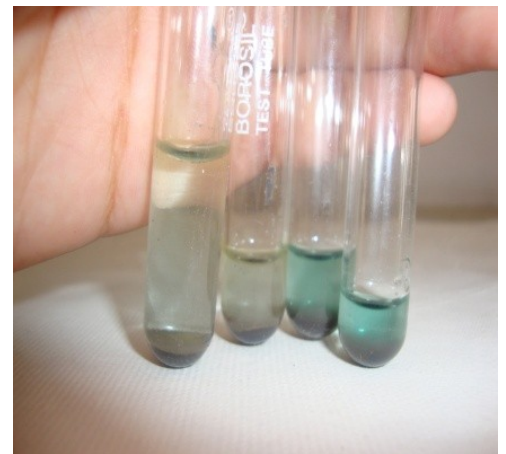

H] BROTH DILUTION SAMPLE II

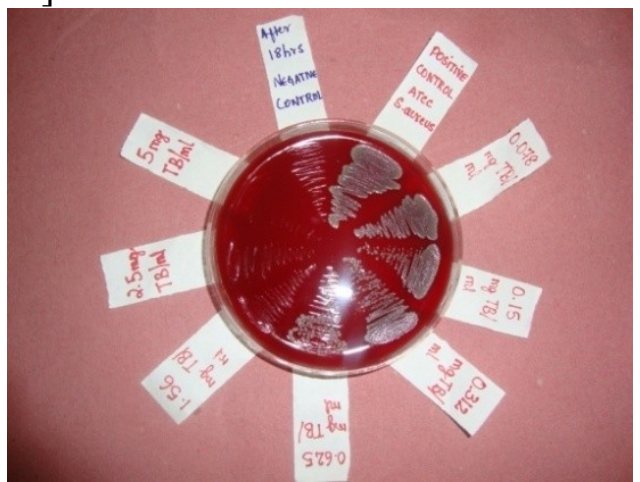

$[\mathbf{J}]$

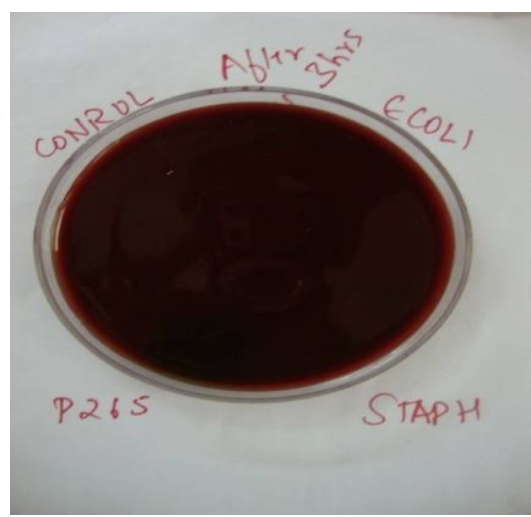

[L] 


\section{RESULTS:}

- The pure bacterial suspension or the positive control group showed bacterial growth.

- The negative control group containing only distilled water showed no bacterial growth.

- The gentamycin showed MBD [minimum bactericidal dose] at $0.01 \mathrm{mg} / \mathrm{ml}$ concentration

- The tamra bhasma solution inhibited bacterial growth at $2.5 \mathrm{mg} / \mathrm{ml}$ concentration for $E$. coli and growth of Staphylococcus was inhibited at $\quad 1.25 \mathrm{mg} / \mathrm{ml}$ concentration.

- The tamra bhasma filtrate inhibited the bacterial growth in equal concentration even after dilution.

\section{DISCUSSION:}

- Antibacterial action of Tamra bhasma i.e kushtaghna, krimighna, jvaraghna properties as said in ancient literature is established

- Tamra bhasma was used in treating rakta vikaras, parinama shula and yakrit vikaras.

- Previous studies on tamra bhasma have proved its hepato protective, antioxidant and antiulcerogenic effect.

- Tamra bhasma given in appropriate doses would have very minimal or no side effects.

- In the present study its anti bacterial action on Ecoli and Staphylococcus was made.

- By the Observations of the results it is proved that tamra bhasnma has antibacterial action and has bactericidal effect on both the bacteria.

\section{CONCLUSION:}

- Tamra bhasma is mentioned in treatment of tvak roga, rakta vikaras and yakrit vikaras.
- Previous studies on tamra have shown that tamra is hepatoprotective in nature and when prepared classically its toxic effects can be nullified.

- Its internal administration with an appropriate dose it may have less or no side effects.

- Here the studies show that tamra bhasma [4 samples] has a good amount of antibacterial effect.

- Further research is required to find its exact therapeutic dose and with clinical studies on infectious disorders it may be used as an ideal medicine in certain bacterial infections.

\section{REFERENCES:}

1. Dr. Ashok Satpute. Gopalkrishnabhatta's Rasendra Sara Sangraha English translation. Varnasi; Choukambha Krishnadasa Acedamy; 2003. p 194

2. Kaviraja Ambikadatta shastri. Vagbhata's Rasaratna samuchachaya English translation. $8^{\text {th }}$ Ed. Varanasi, Choukmba Samskrit Samsthana: 1988

3. Indradeo Tripathi. Panditha Narahari's Raja Nigantu translation. $3^{\text {rd }}$ Ed. Varanasi; Choukambha Krishnadas Academy; 2003. p 432.

4. Kashinath Shastri. Sadananda Sharma's Rasatarangini. $11^{\text {th }}$ Ed. New Delhi; Motilal Banarasidas Publication; 2004. p 408.

5. Acharya Vishwanatha Dvivedi. Bharatiya Rasashastra. $2^{\text {nd }}$ Ed. Varanasi; Shri Sharma Ayurveda Mandir; 1987.

6. Budheva Mukharji. Rasajalanidhi Vol 2, $4^{\text {th }}$ Ed. Varanasi; Chawkhambha Publishers; 2004, p 273.

7. Gulrajsharma Mishra. Acharya Madhava's Ayurveda Prakasha translation. $2^{\text {nd }}$ Ed. Varanasi; Choukambha Bharti Academy; 1999. p 367 
8. Guruprasada, Sharma PV. Dhanvatari Nighantu Translation. $3^{\text {rd }}$ Ed. Varanasi; Chokhambha Orientalia Publication; 2002. p 180.

9. Damodhar Joshi. Yadavji Trikamji Acharya's Rasamritam translation. $1^{\text {st }}$ Ed. Varanasi; Choukambha Sanskrit Sansthan; 1998. p 43.

10. Pandey GS. Bhavamishra's Bhavaprakash Nighantu translation. $9^{\text {th }}$ ed. Varanasi; Chaukhambha Bharathi Academy; 1993. p 6.

11. Nadakrani AK. Indian Materia Medica Volume II, $2^{\text {nd }}$ Ed. Bombay; Popular Prakashan; 1992. p 47.

12. Vaidya Vasudeva Mulashankar Diwedi. Parada vijnanam. $2^{\text {nd }}$ ed. Varanasi; Sharma Ayurveda Mandir 1978.
13. Minerals of India by Meher. D. N. Wadia

14. Anonymous, Pharmacopoeial Standards for Ayurvedic Formulations, New Delhi; CCRAS; 1987

15. Satoskar R.S. and Bhandarkar S.D. Pharmacology Pharmacotherapeutics. $12^{\text {th }}$ ed, Bombay; Popular Prakashan, 1991.

16. Ananthanarayanan R. C. K. Textbook of Microbiology. $4^{\text {th }}$ ed. Madras; Orient Longman Limited; 1990

17. Clayton Thomas. Taber's Cyclopedic Medical Dictionary. $28^{\text {th }}$ ed. New Delhi; Jaypee Brothers Medical Publishers; 1998. 